\title{
Ring with Resurrection Scene from Ummayyad Jerusalem
}

\author{
Yana Tchekhanovets \\ Israel Antiquities Authority
}

\begin{abstract}
The article is dedicated to a Byzantine-Early Islamic ring decorated with a representation of the Resurrection scene, recently discovered in salvage excavations in Jerusalem, at the Givati Parking Lot site. Well-dated stratified context of the find, first of its kind discovered in archaeological excavationns, enables to confirm the traditional dating of similar rings kept in the museums' collections and to discuss their possible function in early Christian pilgrimage practice.
\end{abstract}

Key words: archaeology of pilgrimage, jewelry, contact relics, Byzantine-Islamic transition.

\section{Archaeological Context: Byzantine Street and Its Decline}

Givati Parking Lot is located on the northwestern side of the City of David spur, along the eastern fringes of the Tyropoeon Valley, which delimits the spur from the west (Fig. 1). ${ }^{1}$ The site is in close proximity to the historical nucleus of ancient Jerusalem ("City of David"), and some $30 \mathrm{~m}$ south of the Ottoman wall around the old Jerusalem. The large excavations performed at the site in $2007-2016^{2}$ on the area totaling 0.5 hectares, revealed a stratigraphic and chronological sequence, representing architectural remains dated to wide chronological scope, from the Iron Age (ninth century BC) up to the Abbasid period (ninth-tenth centuries $\mathrm{CE}$ ).

1 The salvage excavations has been carried out in 2007-2016 on behalf of the Israel Antiquities Authority (IAA), under the direction of Doron Ben Ami and the author. This paper could not have been completed without the meticulous and devoted work carried out by S. Bechar, H. Ben-Dov, N. Nisim BenEfraim, O. Bejarno Souroujon, S. Cohen, D. Gutreich, S. Hirshberg, M. Krakovski, F. Kobrin, N. Rom, A. Shatil, N. Sharabi, D. Tanami, and A. Zilberstein (area supervision), V. Essman, M. Kunin, M. Kipnis and Y. Shmidov (surveying), N. Zak and R. Brin (plans), T. Sagiv, A. Peretz, M. Dinstein and C. Amit (photos), G. Bijovsky, D.T. Ariel and A. Berman (numismatics), and I. Reznitski and L. Kupershmit (metal finds cleaning). Deep gratitude should be expressed also to D. Mevorah and M. Wilheim of the Israel Museum and G. Noga-Banai of the Hebrew University of Jerusalem for their generous help and consultation.

2 Ben Ami-Tchekhanovets 2019. 


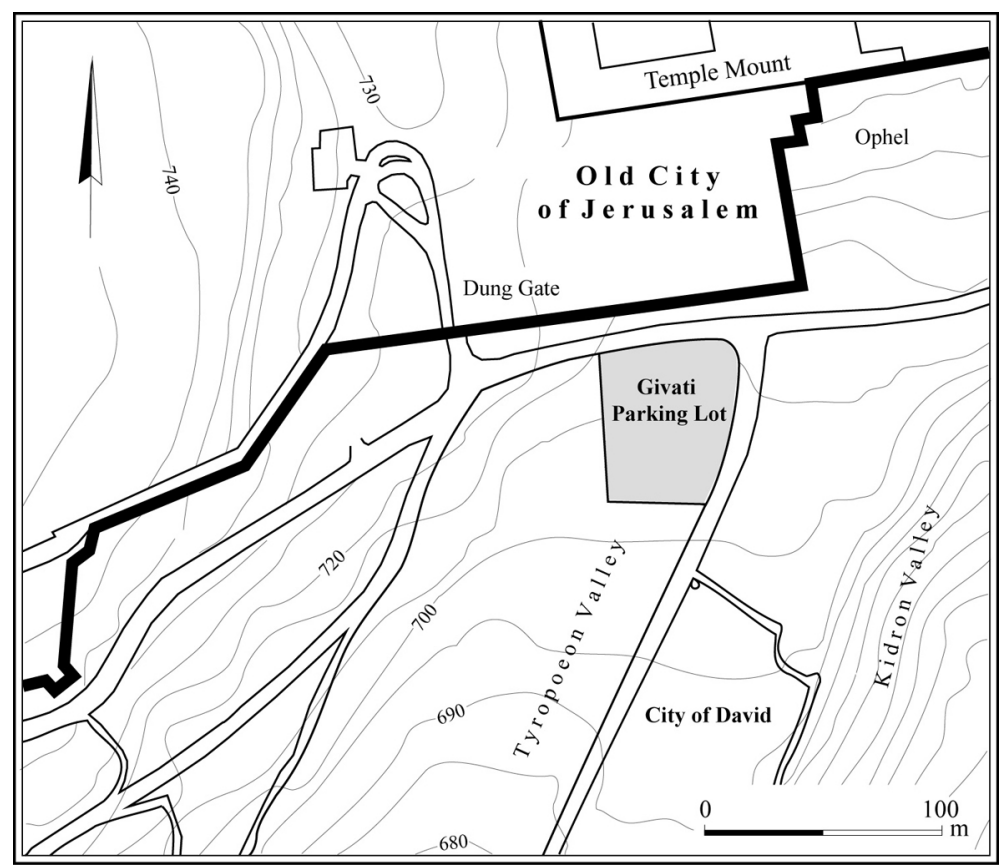

Fig. 1. Givati excavations in Jerusalem, location map (Courtesy of the IAA)

One of the most dominant layers exposed at the site dates to the Byzantine period, specifically to the fifth to early seventh centuries CE. This layer includes an impressive complex, probably administrative in character, discovered in the northern part of the area, two additional buildings in its southern part, and agricultural terrain with a thick layer of garden soil retained by terrace walls. ${ }^{3}$ On the west, the Byzantine administrative building and the garden were flanked by a large paved street (Fig. 2).

In toto, $120 \mathrm{~m}$ of the street are known today archaeologically. ${ }^{4}$ Following the topography of the City of David spur, the street sloped towards the south, with the elevation difference of over five meters, from 701.18 to 695.83 . The street measures ca. $5.5 \mathrm{~m}$ between the curbstones, and is paved with flagstones of various size $(0.4 \times$ $0.4 \mathrm{~m}-0.5 \times 1 \mathrm{~m})$, smooth from long use. The stones were arranged perpendicularly to the north - south axis of the street, typical for pavements of Byzantine period streets exposed elsewhere in Jerusalem. The numismatic material discovered under the flagstones permits to date the pavement to the days of Justinian's rule: a coin generally dated to $527-567 ; 5$ a nummus of Justinian dated to $534-539 ;{ }^{6}$ and fifth-sixth century coins. ${ }^{7}$

\footnotetext{
3 Ben Ami - Tchekhanovets 2010.

4 See also Crowfoot - Fitzgerald 1929, 41-55; Hagbi - Uziel 2015; Hagbi - Uziel 2017.

5 Crowfoot - Fitzgerald 1929, 117.

6 Ariel, forthcoming.

7 Hagbi - Uziel 2015, 45.
} 


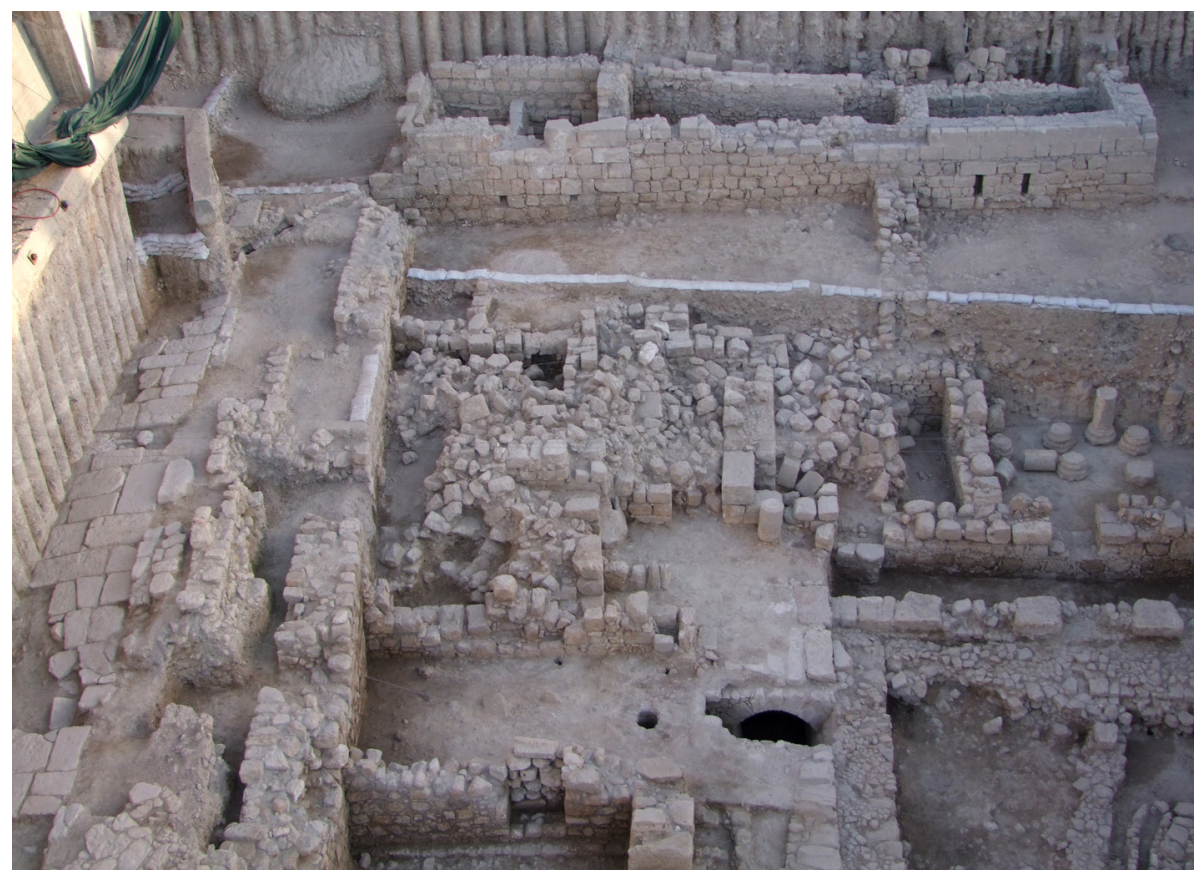

Fig. 2. Byzantine period remains: Byzantine paved street on the left, administrative building of the background. View to the north (Aerial photo: Skyview)

It seems that the revealed sections of the pavement represent one of the principle streets of Byzantine Jerusalem, ${ }^{8}$ which served as an important pilgrimage route connecting the sanctuaries of the city center to the Pool of Siloam pool, ${ }^{9}$ a venerated Christian site, the place of the Healing of the Blind, ${ }^{10}$ with a church seen at the pool already by the Pilgrim of Piacenza, ca. 570. ${ }^{11}$ During the later stages of the Byzantine rule, the entire region between the pool and the city center was turned into a thriving pilgrimage area. A series of the shops were built along the paved street, ${ }^{12}$ supplying the needs of the numerous passersby. Byzantine street running along the Tyropoeon Valley on a list of "liturgical streets" of the Holy City, ${ }^{13}$ built on the higher parts of the slope, linking the holy sites and covering certain segments of pilgrim routes. Worth mention in this regard is a miniature bone box, adorned with two painted icons inside (Fig. 3), which was discovered on the pedestrian sidewalk of the Byzantine street. ${ }^{14}$

It is difficult to propose an unequivocal explanation for the end of Byzantine structures built along the paved street. The large administrative building discovered in the

8 Tsafrir 1999, 295-300, 321-323; Gutfeld 2011.

9 Baert 2014.

10 John 9:1-12.

11 Voltaggio 2012, 112-115.

12 Crowfoot - Fitzgerald 1929, 51.

13 Voltaggio 2012, 107-123.

14 Tchekhanovets 2014. 


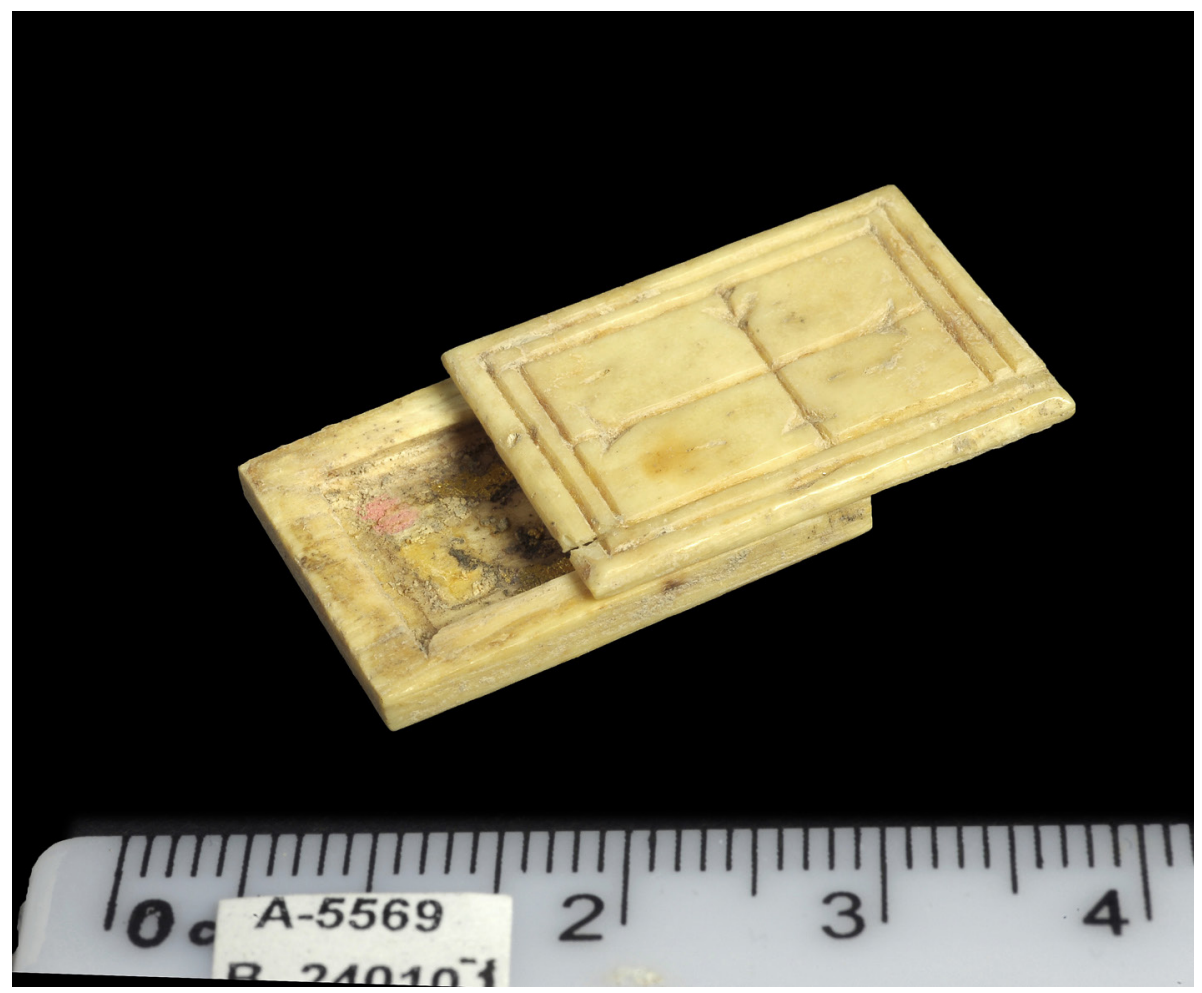

Fig. 3. Miniature icon box from Givati (Photo: C. Amit, IAA)

Givati Parking Lot met a violent end, precisely dated by a large hoard of unused gold solidi of Emperor Heraclius, minted between 610 and 613 and sealed under the debris of a ruined structure. ${ }^{15}$ It is possible that parts of the street went out of use in different times. The destruction layer locally exposed directly above the paved street should be dated to the second half of the seventh century. ${ }^{16}$ This impressive collapse, located at the southern end of the Givati excavation, contained ashlars and numerous profiled architectural fragments, originating from a monumental structure located east of the street.

During the Umayyad period the entire area was turned into industrial zone, and the street went out of use or was significantly narrowed (Fig. 4). Some of the pavement slabs were damaged or entirely removed, and no buildings of any kind were constructed along it other than a few carelessly built walls and fragmentary preserved plaster floors, mainly associated with a large lime kiln, discovered in the northwestern part of the excavated area, or with a small-scale metallurgical workshop discovered in the southwest, dated to the first half of the seventh century CE. ${ }^{17}$ Prior to the renewed Abbasid building activity at the site, dated to the second half of the eighth century, the entire area was abandoned

15 Bijovsky 2010.

16 Bijovsky, forthcoming.

17 Tchekhanovets 2018 . 


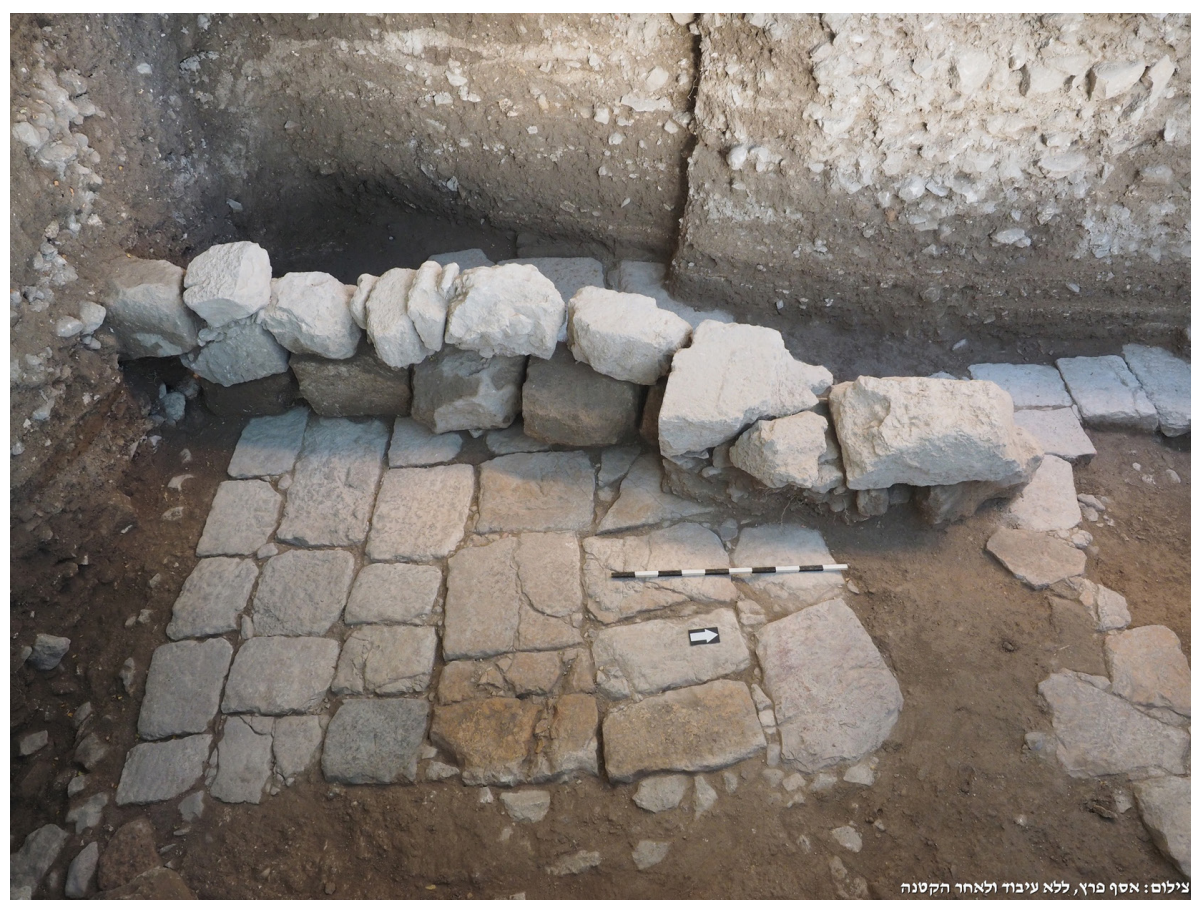

Fig. 4. Street in its decline: Early Islamic wall built upon the pavement. View to the west (Photo: A. Peretz, IAA)

and was covered by thick layers $(0.4-0.8 \mathrm{~m})$ of alluvium. Finds revealed in this context include pottery fragments dated to the Late Byzantine-Early Islamic period and a copper alloy ring, decorated with a scene of Resurrection. According to stratigraphical sequence, the archaeological context of the ring from Givati can be safely dated to the late seventh-first half of the eighth century.

\section{The Ring (Fig. 5)}

The cooper alloy ring ${ }^{18}$ is supplied with thin, octagonal hoop, flattened from the internal side, D $1.7 \mathrm{~cm}$; thin oval bezel, $1.3 \times 1 \mathrm{~cm}$; decorated with engraved design: at the right side, large seating figure with a halo, head to the left, raised object in the right hand; at the left side, two smaller standing figures in draped cloth; in the center, small structure with a conic dome, crowned with a cross; border of dots on the right edge.

Figures represent a part of Resurrection scene: Women the Myrrhbearers near the empty tomb of Christ, greeted by an angel, holding a censer. The Holy Tomb is symbolically represented by a cross-crowned gabled aedicula, commemorating the site, well known from other artifacts dated to the Byzantine period: paintings, mosaics, ampullae,

\footnotetext{
18 Israel Antiquities Authority Inv. no. A7721/2016, B10206.
} 

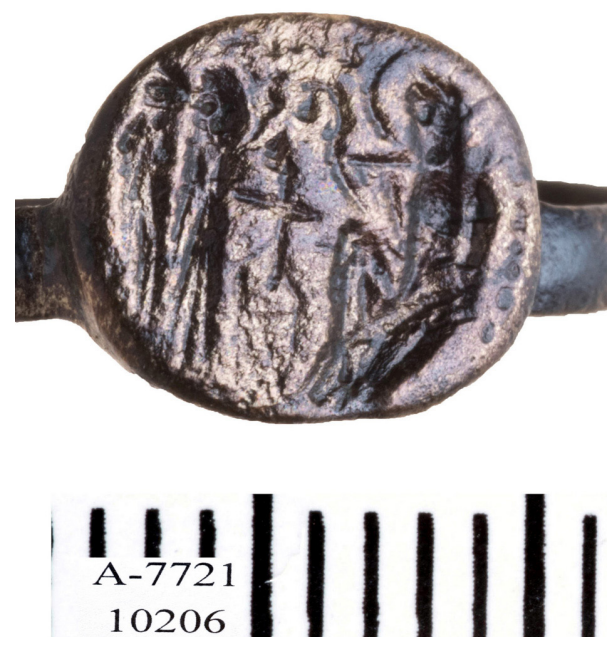

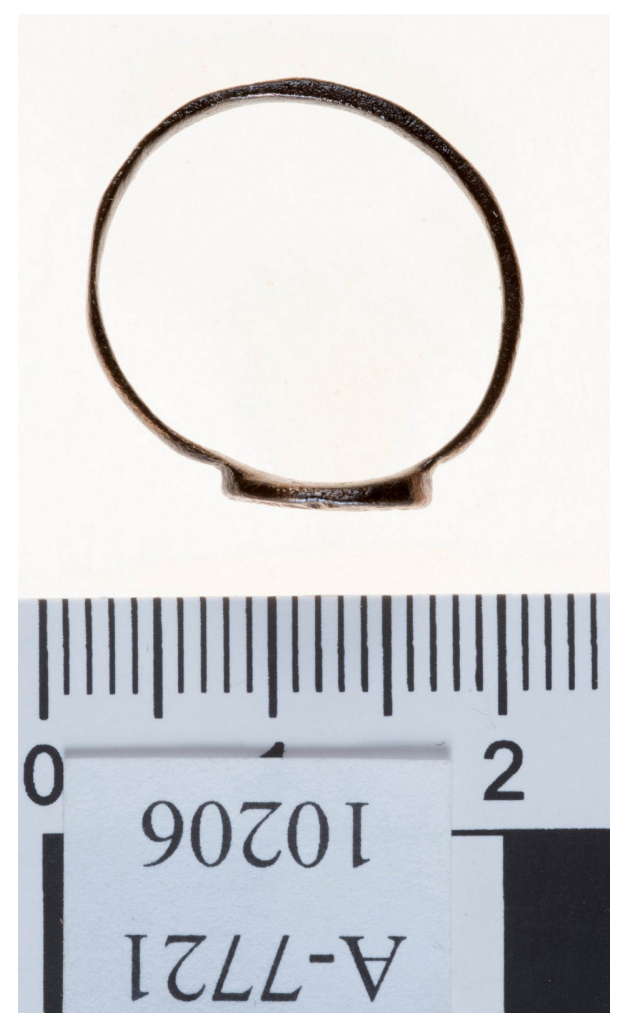

Fig. 5. Ring with a scene of Resurrection (Photo: C. Amit, IAA)

jewelry, glass bottles etc., reflecting the actual state of the monument in that period. ${ }^{19}$ On the humble ring from Jerusalem, as on the simple earthen eulogia token $\mathrm{s}^{20}$ and glass vessels $^{21}$ the edifice is given only in general outlines, with a crowning cross as a main characteristic detail. These visual sources, together with contemporary written accounts and the results of the archaeological soundings at the site permit to reconstruct the tomb hewn from the rock, and crowned by a canopy, supported by pillars. ${ }^{22}$

\section{Discussion}

Three similar copper alloy rings, roughly dated to the sixth-seventh centuries, are kept in the funds of the Israel Museum in Jerusalem, being a part of the Byzantine collection, inherited by the Museum from Prof. Dan Barag. ${ }^{23}$ The iconography of the scene on the

19 Weitzmann 1974; Biddle 1999, 20-28.

20 Rahmani 1993, 111, Fig. 5.

21 Barag 1970/1971, Fig. A: VII.

22 Patrich 2016, 146.

23 Israel Museum, inv. nos. 2010.65.1137; 2010.65.1146; 2010.65.1233. Dan Barag (1935-2009), numismatist and specialist on ancient glass of the Institute of Archaeology of the Hebrew University of Jeru- 
three unprovenanced examples from Israel Museum and Givati ring is closed, but not identical. The engraving technic of the rings is similar to those used for signets, but at all the four the iconography is given in positive, with angel on the left and Myrrhbearers on the right. It seems that similarly to other rings with Christological scenes, it was not intend to be used as a seal, but rather as sort of a pilgrim eulogia, protecting its owner by the power of the depicted holy site.

The closest contemporary parallels to the depicted scene of Resurrection can be found with elaborated eulogia ampullae preserved in Monza and Bobbio, produced for pilgrims' use in the Byzantine Palestine. Here, Women at the Tomb serve a popular decorative motif, both as an independent scene ${ }^{24}$ and as a part of larger composition of the Resurrection. ${ }^{25}$ The detailed composition decorating the ampullae is reflected in the simplified depiction on our ring, proposing in the most schematic, but still recognizable iconography. In general, the images, already developed and popularized in other media, became favorite decorative motives of "iconic" rings and armbands, made of gold or cheaper metals, brass and bronze, most probably produced in the Syro-Palestinian region. ${ }^{26}$

The peak of popularity of jewelry with holy sites and saints is dated to the second half of the sixth-mid-seventh centuries CE ${ }^{27}$ Christian rings with Christological scenes, mainly made of gold, are well known from the museum collections; ${ }^{28}$ and also from the excavations in the region. ${ }^{29}$ Possibly, such rings served as "contact relics", mediators between their owners and the holy site itself, visited, touched, remembered or even unseen. ${ }^{30}$

The presented Resurrection ring, together with a small icon box, previously found at Givati excavation in Jerusalem, enables a peek on the early practices of private Christian devotion at the Holy Land. Well stratified and dated archaeological context of these rare finds - the paved street, still serving as important pilgrimage artery of the city during the Early Islamic period, - present them as close to their "natural environment" as it can be obtained by archaeological methods.

salem. Passionate antiquarian, he continued to collect the artifacts related to the Christian pilgrimage to the Holy Land. The unprovenanced finds of this collection are mainly attributed to the Syro-Palestinian region and are generally dated to the fourth-eleventh centuries $\mathrm{CE}$.

24 Grabar 1958: Pls. IX, XI-XIII, Nos. Monza 3, 5, 6, 8.

25 Grabar 1958: Pls. V, XIV, XVI, XVIII, XXII, XXIV, XXVI, XXVIII, XXXIV-XXXVII, XL, XLV, XLVII, Nos. Monza 2, 9-15 and Bobbio 3-7, 15, 18.

26 Vikan 1987; Vikan 1991/1992.

27 Rahmani 1985, 179.

28 Dalton 1912, 7, no. 40; Ross 1962, Pl. E:69; Zalesskaya 2006, nos. 81, 84, 85, 89.

29 For example, Gush Halav: Makhouly 1939, 48, Pl. 31: 9; Kursi: Tzaferis - Bijovsky 2014, Fig. 18:2; Ziqim: Rahmani 1985, 176.

30 For early practice of touching relics, see Wiśniewski 2018, 122-143. Compare to the Medieval custom to send the jewels to the Holy Land with a trustful men, who will provide a physical contact with the sacred spots and relics. This custom is described in detail by Fr. Felix Fabri, a Swiss pilgrim to the Holy Land, during his visit to the Monastery of St. Catherine at the Sinai in 1483: “... our noblemen gave me all their jewels of gold and jewels of silver, that I might touch the holy relics with them. So I took both the jewels which had been entrusted to me at Ulm by those dear to me, and those of my comrades their lordships the knights, and put each one of them into the coffin, touching with them the noble virgin's sacred head" (Fabri, English transl. by Stewart 1893, 600). 


\section{BIBLIOGRAPHY}

Ariel, D.T. (forthcoming), The Coins of the Byzantine Stratum, in: D. Ben Ami, Y. Tchekhanovets (eds.), Jerusalem: Excavations in the Tyropoeon Valley (Givati Parking Lot), vol. II (IAA Reports), Jerusalem.

Baert, B. (2014), Lavit et venit videns: The Healing of the Blind Man at the Pool of Siloam, in: B. Kuhnel, G. Noga-Banai, H. Vorholt (eds.), Visual Constructs of Jerusalem, Turnhout: 23-34.

Barag, D. (1970/1971), Glass Pilgrim Vessels from Jerusalem, Journal of Glass Studies 12: 35-63; 13: 45-63.

Ben Ami, D., Tchekhanovets. Y. (2010), Jerusalem, Givati Parking Lot, HA-ESI 122, http://www.hadashot-esi.org.il/report_detail_eng.aspx?id=1377\&mag_id=117 (access: 27.11.2019).

Ben Ami, D., Tchekhanovets, Y. (2019), The Givati Excavation Project 2007-2015: From the Iron Age to the Early Islamic Period, in: H. Geva (ed.), Ancient Jerusalem Revealed: Archaeological Discoveries 1998-2018, Jerusalem: 264-278.

Biddle, M. (1999), The Tomb of Christ, Phoenix.

Bijovsky, G. (2010), A Single Die Solidi Hoard of Heraclius from Jerusalem, in: Mélanges Cecile Morrisson, (Travaux et Memoirs 16), Paris: 55-92.

Bijovsky, G. (forthcoming), Coins from Excavations in Givati Parking Lot, 'Atiqot.

Crowfoot, J. W., Fitzgerald, G. M. (1929), Excavations in the Tyropoeon Valley, Jerusalem, 1927, London.

Dalton, O. (1912), Catalogue of the Finger Rings, Early Christian, Byzantine, Teutonic, Medieval and Later, London.

Fabri, F. (1893), The Book of the Wanderings, vol. II/2, English translation by A. Stewart, London.

Grabar, A. (1958), Les ampoules de Terre Sainte (Monza-Bobbio), Paris.

Gutfeld, O. (2011), The Urban Layout of Byzantine-Period Jerusalem, in: K. Galor, G. Avni (eds.), Unearthing Jerusalem: 150 Years of Archaeological Research in the Holy City, Winona Lake: 327-350.

Hagbi, M., Uziel, J. (2015), The Hill of the City of David during the Byzantine Period: A View from the Byzantine Street, City of David Studies in Ancient Jerusalem 10: 41-53 (Hebrew).

Hagbi, M., Uziel, J. (2017), Jerusalem, City of David, the Byzantine Street, HA-ESI 129: http://www. hadashot-esi.org.i1/report_detail_eng.aspx?id=25185\&mag_id=125 (access: 27.11.2019).

Makhouly, N. (1939), Rock-Cut Tombs at el-Jish, QDAP 8: 45-50.

Patrich, J. (2016), An Overview of Archaeological Work in the Church of the Holy Sepulchre, in: D. Vieweger, S. Gibson (eds.), The Archaeology and History of the Church of the Redeemer and the Muristan in Jerusalem, Oxford: 139-162.

Rahmani, L. Y. (1985), On some Byzantine Brass Rings in the State Collection, 'Atiqot 17:168-181.

Rahmani, L. Y. (1993), Eulogia Tokens from Byzantine Beth-Shean, 'Atiqot 22: 109-119.

Ross, M. C. (1962), Catalogue of the Byzantine and Early Medieval Antiquities in the Dumbarton Oaks Collection, vol. I, Washington, DC.

Tchekhanovets, Y. (2014). Miniature Diptych from Jerusalem, Bizantinische Zeitschrift 107/2, 893-902.

Tchekhanovets, Y. (2018), Recycling the Glory of Byzantium: New Archaeological Evidence of Byzantine-Islamic Transition in Jerusalem, Studies in Late Antiquity 2: 215-237.

Tsafrir, Y. (1999), Topography and Archaeology of Jerusalem in the Byzantine Period, in: Y. Tsafrir, S. Safrai (eds.), The History of Jerusalem: The Roman and Byzantine Periods, 70-638, Jerusalem: 281-352 (Hebrew).

Tzaferis, V., Bijovsky, G. (2014), New Archaeological Finds from Kursi - Gergesa, 'Atiqot 79: 175197.

Vikan, G. (1987), Early Christian and Byzantine Rings in the Zucker Family Collection, The Journal of the Walters Art Gallery 45: 32-43. 
Vikan, G. (1991/1992), Two Byzantine Amuletic Armbands and the Group to Which They Belong, The Journal of the Walters Art Gallery 49/50: 33-51.

Voltaggio, M. (2012), Hagia Polis Hierosalyma: Birth and Development of Jerusalem Christian Topography, Temporis Signa 7: 107-123.

Weitzmann, K. (1974), Loca sancta and the Presentational Arts of Palestine, Dumbarton Oaks Papers 28: $31-55$.

Wiśniewski, R. (2018), The Beginnings of the Cult of Relics, Oxford.

Zalesskaya, V. (2006), Monuments of Byzantine Applied Arts, $4^{\text {th }}-7^{\text {th }}$ Centuries: Catalogue of the Hermitage Collection, St. Petersburg (Russian). 